\title{
Nephrocutaneous Fistula: An Unusual Nephrectomy Indication in Percutaneous Nephrolithotomy
}

\author{
Nefrokutanöz Fistül: Perkütan Nefrolitotomide Ender Bir Nefrektomi Nedeni
}

\author{
(1) Mehmet Yiğit Yalçın1, (1) Cemal Selçuk İşoğlu2 2, (1) Mustafa Karabıçak ${ }^{3}$, (1) Batuhan Ergani1, (1) Taha Çetin1, \\ (D) Mert Hamza Özbilen1, (D) Tufan Süelözgen1, (D) Gökhan Koç1, (D) Yusuf Özlem İlbey \\ 1 University of Health Sciences, Izmir Tepecik Training and Research Hospital, Clinic of Urology, Izmir, Turkiye \\ 2Ceyhan State Hospital, Clinic of Urology, Adana, Turkiye \\ ${ }^{3}$ Batman Region State Hospital, Clinic of Urology, Batman, Turkiye
}

\begin{abstract}
Percutaneous nephrolithotomy (PNL) is recognized as the gold standard treatment method for stones larger than $2 \mathrm{~cm}$ due to its high success and acceptably low complication rates. The complications of PNL are well defined. Prolonged urinary leakage is one of them. In this study, a case of post-PNL urine leakage that was eventually treated with nephrectomy is discussed.
\end{abstract}

Keywords: Prolonged urinary leakage, Nephrocutaneous fistula, Percutaneous nephrolithotomy

Öz

Perkütan nefrolitotomi (PNL) yüksek başarı ve kabul edilebilir komplikasyon oranlarından dolayı 2 cm'den büyük taşlar için altın standart tedavi yöntemi olarak kabul edilmektedir. PNL'nin komplikasyonları iyi tanımlanmıştır. Uzamış idrar kaçağı bunlardan biridir. Bu çalışmada PNL sonrası idrar kaçağı devam eden ve sonrasında nefrektomi ile tedavi edilen bir olgu tartışılmıştır.

Anahtar Kelimeler: Uzamış idrar kaçağı, Nefrokutanöz fistül, Perkütan nefrolitotomi

\section{Introduction}

Percutaneous nephrolithotomy (PNL) is recognized as the gold standard treatment method for stones larger than $2 \mathrm{~cm}$ due to its high success and acceptably low complication rates (1). The complications of PNL are well defined. Prolonged urinary leakage is one of them. Urinary leakage after nephrostomy tube removal is considered normal up to a certain extent and until the tract heals, except for cases of ureteral obstruction where the leakage continues and requires intervention (2). In this study, a case of post-PNL urine leakage that was eventually treated with nephrectomy is discussed.

\section{Case Presentation}

A 20-year-old woman was admitted to our clinic with the complaints of left-sided pain persisting for 1 year. Her medical and family history was unexceptional. Her physical examination was normal and the blood test results were within the normal limits. Her urine culture yielded $105 \mathrm{CFU} / \mathrm{mL}$ Escherichia coli. Non-contrast computed tomography (CT) of the abdomen showed a staghorn stone in the left kidney (Figure 1). Renal scintigraphy displayed $41 \%$ contribution of the left kidney to total renal function as well as tubular dysfunction in addition to parenchymal and cortical hypoactive large deformation areas. PNL was planned when no bacterial growth was detected in the urine culture following antibiotic therapy. PNL was performed through 3 different accesses in the upper, middle and lower calyces. One nephrostomy tube was placed at the end of the operation and the other access sites were closed primarily. There were no intraoperative complications. Two units of erythrocyte transfusion were given due to postoperative haemodynamic instability. Hemodynamic stability was achieved and the patient was discharged without any problems on the postoperative third day.

Correspondence: Mehmet Yiğit Yalçın MD, University of Health Sciences, İzmir Tepecik Training and Research Hospital, Clinic of Urology, İzmir, Turkiye Phone: +90 5073469268 E-mail: yigityalcin@ hotmail.com ORCID-ID: orcid.org/0000-0001-9943-7453

Received: 29.04 .2018

Accepted: 12.06 .2018

Cite this article as: Yalçın MY, İşoğlu CS, Karabıçak M, Ergani B, Çetin T, Özbilen MH, Süelözgen T, Koç G, İlbey YÖ. Nephrocutaneous Fistula: An Unusual Nephrectomy Indication in Percutaneous Nephrolithotomy. J Urol Surg 2019;6(1):59-61.

๑Copyright 2019 by the Association of Urological Surgery / Journal of Urological Surgery published by Galenos Publishing House. 
The patient was admitted again on the postoperative seventh day with the complaint of continuing urinary leakage from the incision site. Non-contrast CT of the abdomen revealed residual stones of $18 \times 10$ and $25 \times 12 \mathrm{~mm}$ in the posterior middle and lower calyces of the left kidney. A double J stent (DJS) was inserted. Urinary leakage disappeared and the patient was discharged and scheduled to be followed up after 1 month. In the control visit, the DJS was removed. After the procedure, the patient was admitted once again with the complaint of leakage from the wound site. She was hospitalized and antibiotherapy was initiated upon positive urine culture. Again, a DJS was inserted. She was discharged and a follow-up for urine culture was planned but the patient did not attend the follow-up visit. Four months after the last control, she presented with purulent discharge from the wound site despite the DJS. Antibiotherapy was initiated and non-contrast CT of the abdomen was taken (Figure 2). CT revealed parenchymal thinning; hence, renal cortical scintigraphy was repeated. Since the left kidney was observed to get smaller in size than the right one, and due extensive parenchymal dysfunction and 9\% contribution of the left kidney to total kidney function, the patient underwent nephrectomy.

Written informed consent was taken for publication of the case report.

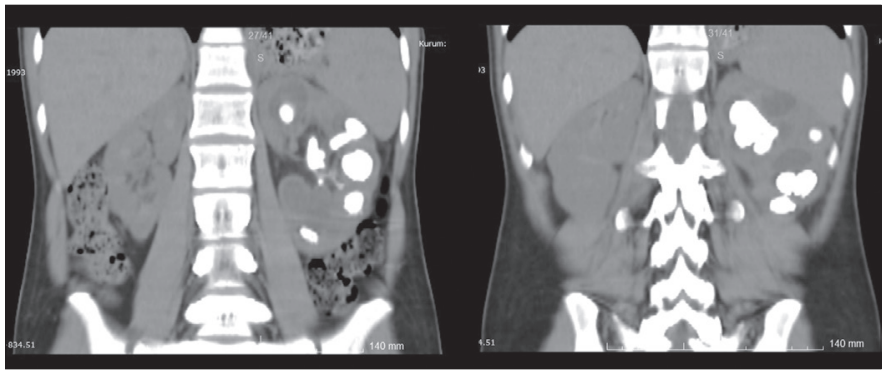

Figure 1. Preoperative multipl stones in the left kidney on computed tomography

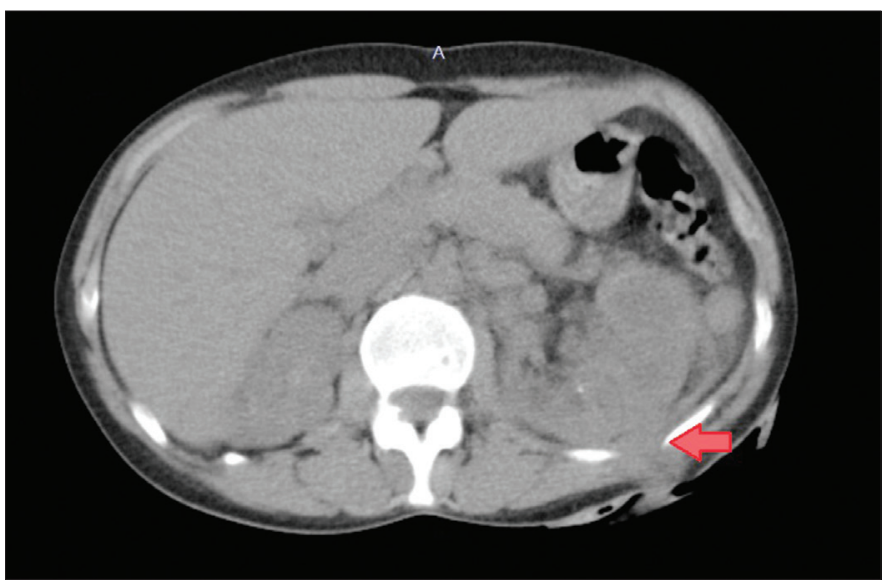

Figure 2. Tract of nephrocutaneous fistula in the left kidney on computed tomography

\section{Discussion}

After the publication of the first PNL series by Wickham and Kellet (3) in 1981, the method of open stone surgery has been almost abandoned. In a study conducted with 12.000 patients, the rate of PNL complications was reported to be $10.8 \%$ for fever, $7 \%$ for transfusion, 1.5\% for thoracic complication, $0.5 \%$ for sepsis, $0.4 \%$ for organ injury and $0.4 \%$ for embolization (4). Prolonged urinary leakage is one of them. Urinary leakage after the removal of nephrostomy tube is considered normal up to a certain extent and until the tract heals. The most common complication requiring reoperation with a frequency rate of $4 \%$ is prolonged urinary leakage from the tract, exceeding 24 hours (5). Urinary leakage occurs due to peripheral obstruction because of a stone or a clot. It is usually treated with DJS insertion (2). In a study, it has been reported that it was only the presence of preoperative hydronephrosis that was increasing prolonged urinary leakage and its duration, while the size of the stone, the number of accesses, and the shape of the used sheath had no influence (6). There was no preoperative hydronephrosis to predict prolonged urinary leakage in our case.

Spontaneous nephrocutaneous fistulas usually occur in nonfunctioning or weakly functioning kidneys. Lewi and Scott (7) pointed out three correlations between nephrocutaneous fistula and renal stones: 1) presentation with perinephric abscess, 2) presence of staghorn stone in the non-functioning kidney, 3) presence of peripherically located stones in radiography. Unlike the study by Lewi and Scott (7), nephrocutaneous fistula after PNL is discussed in our case, however, renal deformation, presence of staghorn type peripheral stones, and recurrent urinary infections in the postoperative period are similar findings.

There are very few data available in the literature on the treatment of post-PNL nephrocutaneous fistulas. Treatment modality for the fistulas continuing after elimination of the obstructive causes is not clear. Resection of the fistula tract is the standard treatment for urinary fistulas (8), but several studies reported positive results with fibrin glue injection for nephrocutaneous fistula treatment (9). Resection of the fistula tract and fibrin glue injection were not considered in our case because of purulent discharge from the kidney and dysfunction of the kidney over time, and, thus, nephrectomy was planned.

In conclusion, DJS can be attempted primarily in uncomplicated nephrocutaneous fistula treatment. As a remedy in case of failure, blocking the tract with fibrin glue and surgical excision of the tract may be considered as an option in the treatment. Factors affecting systemic healing, such as therapy-resistant urinary infection, may increase the risks such as developing nephrocutaneous fistula and failure in closing by conservative 
method as well as the consequences leading to organ loss, as we encountered in our case.

\section{Ethics}

Informed Consent: Written informed consent was taken for publication of the case report.

Peer-review: Externally peer-reviewed.

\section{Authorship Contributions}

Concept: M.Y.Y., Design: T.S., M.Y.Y., Data Collection or Processing: T.Ç., M.H.Ö., Analysis or Interpretation: Y.Ö.I., G.K., Literature Search: M.K., B.E., Writing: M.Y.Y., T.S., C.S.I.

Conflict of Interest: No conflict of interest was declared by the authors.

Financial Disclosure: The authors declared that this study received no financial support

\section{References}

1. Türk C, Knoll T, Petrik A, Sarica K, Skolarikos A, Straub M, Seitz C. Guidelines Associates.In: Dabestani $S$, Drake $T$, Grivas $N$, Ruhayel $Y$, Tepeler AK. Guidelines on Urolithiasis. European Association of Urology, 2016.
2. Kyriazis I, Panagopoulos V, Kallidonis $P$, Özsoy $M$, Vasilas $M$, Liatsikos E. Complications in percutaneous nephrolithotomy. World J Urol 2015;33:1069-1077.

3. Wickham JE, Kellet MJ. Percutaneous nephrolithotomy. $\mathrm{Br}$ Med J 1981;283:1571-1572.

4. Seitz C, Desai M, Hacker A, Hakenberg OW, Liatsikos E, Nagele U, Tolley D. Incidence, prevention, and management of complications following percutaneous nephrolitholapaxy. Eur Urol 2012;61:146-158.

5. Tefekli A, Karadag MA, Tepeler K, Sari E, Berberoglu Y, Baykal M, Sarılar Ö, Müslümanoğlu AY. Classification of percutaneous nephrolithotomy complications using the modified Clavien grading system: looking for a standard. Eur Urol 2008;53:184-190.

6. Dirim A, Turunc T, Kuzgunbay B, Hasirci E, Tekin MI, Ozkardes H. Which factors may effect urinary leakage following percutaneous nephrolithotomy? World J Urol 2011;29:761-766.

7. Lewi HJ, Scott R. Calculocutaneous sinus. Urology 1986;28:232-234.

8. Witten DM, Myers GH, Utz DC. Fistulas of the urinary tract. In: Witten DM, Myers GH, Utz DC. Emmett's clinical urography, 4th WB Saunders, Philadelphia, 1977, pp 1767-1784.

9. Sharma SK, Perry KT, Turk TM. Endoscopic injection of fibrin glue for the treatment of urinary tract pathology. J Endourol 2005;19:419-423. 